\title{
Noen psykodynamiske perspektiver på selvmordsprosessen
}

\author{
Ved Jarl Jørstad
}

Det er mange som i en vanskelig liussituasjon har selvmordstanker, men bare hos noen er det en skjult prosess som fører til at de virkelig tar sitt liv. For å forstå mer av dette er det viktig at vi skjønner både de aktuelle tap og krenkelser som har skjedd, og den mer ubevisste sårbarhet som oftest har røtter tilbake til liknende traumer i barndommen, og hvor en genetisk sårbarhet også kan spille en rolle.

$H$ va er det som får noen til å gjennomføre det som mange bare har som en fantasi?

$\mathrm{N}$ oen selvmord skjer planlagt og etter bevisste overveielser, mens andre skjer impulsivt og i affekt, ofte under påvirkning av alkohol. De fleste viser tegn på depresjon, men det vil alltid være et samspill mellom mange forskjellige følelser, affekter og forhold til nære personer som fører til en suicidal handling. Sentralt i psykodynamisk (psykoanalytisk orientert) teori og klinisk erfaring er samspillet mellom barndom og voksen alder, noe som også gjelder bakgrunnen for mange suicidale handlinger. Traumer og mangler i barndommen kan ha skapt en ubevisst sårbarhet, som i tillegg til en eventuell genetisk sårbarhet, bidrar til at nye og liknende traumer senere i livet kan utløse en psykisk lidelse. Denne sammenhengen mellom fortid og nåtid er viktig når vi forsøker å forstå sel vmordsprosessen. M en utviklingen fra tanke til handling kan være skjult for omgivelsene, og ofte også ubevisst for personen selv. Det gjennomførte selvmordet kan derfor noen ganger tilsynelaten de komme helt uventet, "som lyn fra klar himmel". M en ofte vil små tegn eller endringer i den suicidale personens atferd kunne varsle hva som kan komme til å skje.

I dette store problemområdet kan jeg her bare nevne noen fă, men etter min mening viktige psykodynamiske perspektiver på selvmordsprosessen.

\section{A bli forlatt - \\ tap og separasjon}

Det vi alle er mest sårbare for, er atskillelse og tap (H olmes og Rahe 1967). D et er derfor forståelig at et av de vanligst utIøsende traumer ved selvmord er å bli forlatt av en person som oppleves livsviktig. Spesielt alvorlig er det hvis en mor eller far har gjort selvmord. En forventning eller trussel om å bli forlatt kan være nok. $\mathrm{N}$ år reaksjonen kan bli så sterk, skyldes det nettopp at det i barndommen har skjedd et tap som i voksen alder er ubevisst. Et nytt tap senere i livet kan derfor utløse en suicidal handling. Betydningen av barndomstraumet avhenger av barnets alder ved det første tapet, hvor lenge en eventuell separasjon har vart, og graden av sårbarhet som det har etterlatt. Vi vet mye om slike tidlige separasjoner gjennom forskning på spedbarn og mor-barn-forhold, og i psykoanalytiske erfaringer med voksne. Spitz viste at slike tidl ige tap kan være dødelige i seg selv, særlig hvis spedbarnet først har opplevd noe godt ved mors bryst i flere måneder, og så plutselig blir skilt fra moren i lengre tid (Spitz 1965). A ndre har vist hvordan tidlige tap av foreldre ved død, sykdom eller skilsmisse kan få alvorlige konsekven ser for barns personlighetsutvikling og senere psykiske lidelser (Bowlby 1966). Sårbarheten er størst de første tre årene, før barnet har utviklet objektkonstans, det vil si evnen til å holde fast på et indre bilde av personen når han/ hun ikke er fysisk til stede, "ute av øye ute av sinn" (M ahler et al. 1975).

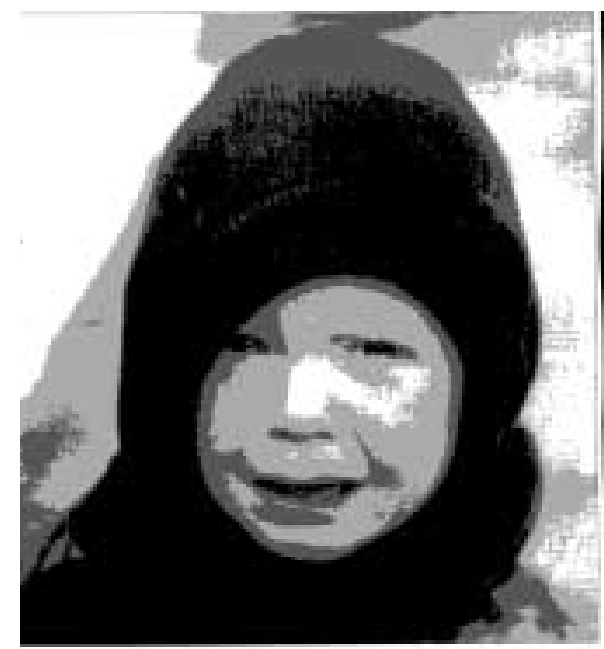

U vitenheten har vært stor om hvor viktig det tidlige mor-barn-forholdet er.

$M$ ange voksne personer har tidlige separasjonstraumer, med en latent angst for tap og atskillel se, en separasjonsangst, som de ubevisst forsøker å bygge et forsvar mot. N oen forsøker kanskje å unngå å bli avhengige av andre eller knytte seg nært til noen. A ndre har ubevisst utviklet en motsatt strategi. De har eller finner et menneske som de utvikler et symbiotisk avhengighetsforhold til, og hvor de med alle midler forsøker å få kontroll over denne personen. M ister de denne kontrollen, kan det starte en selvmordsprosess. Symbiotiske bindinger mellom mor og barn kan også bli enormt sterke. $\mathrm{H}$ vis den ene eller andre av partene i en slik symbiose begynner å frigjøre seg, kan det utløse selvmord.

Et eksempel på det gjorde sterkt inntrykk på meg da jeg som ung lege i spesialistutdannelse opplevde at en 24 år gammel pasient på et psykiatrisk sykehus med diagnosen schizofreni begynte å bli frisk, og som ledd i det ble mer selvstendig i forhold til moren. M oren som var enke, hadde bygget hele sitt liv på datteren, og tok da livet av seg. $\mathrm{H}$ un tålte ikke datterens begynnende frigjøring. $\mathrm{Vi}$ som arbeidet med denne pasienten i avdelingen, forsto ikke den gangen at det alltid er to personer $i$ en symbiose, og at begge parter er bundet sammen med sterke emosjonelle bånd. I en behandlingssituasjon må derfor begge tas vare på og få hjelp til å komme løs.

Et annet eksempel på en slik symbiose var en voksen sønn med A D H D og symbiotisk binding til moren som var skilt. I en årrekke tyranniserte han henne ved å forsøke å kontrollere henne døgnet rundt, og med trusler og fysisk vold hindre henne i å ha et selvstendig liv. M oren hadde selv vanskelig for å sette grenser for sønnen, og måtte flere ganger innlegges på psykiatrisk sykehus på grunn av akutt, stor selvmordsfare. Etter mange år med dramatiske situasjoner og lange uten-

landsreiser klarte moren etter hvert å komme løs, noe som også ble til hjelp for sønnen.

Jeg har opplevd flere voksne pasienter med depresjon og sterke suicidale impulser etter aktuelle tap: Før treårsalderen hadde de blitt plassert i seks uker på Tomtebo "rekonvalesenthjem" for små barn, hvis de f. eks viste tegn på å vantrivsel, spiste for lite og derfor gikk ned i vekt, eller foreldrene skulle reise 


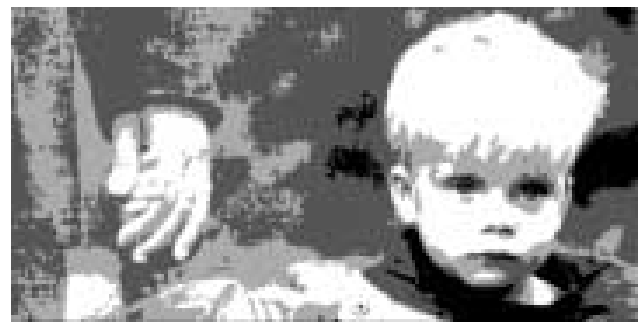

til utlandet. Foreldrene fikk ikke si farvel og ikke komme på besøk, for da ble det for mye bråk! A nbefalingen til denne mishandlingen av barn ble gitt av en professor i barnesykdommer for 40 - 50 år siden. Psykologiske årsaker til slike symptomer var ukjent for ham, og barnepsykiatrien i N orge var i sin spede begynnelse.

\section{I psykoanalytisk psykoterapi har jeg} opplevd at noen pasienter med forskjellige lidelser etter flere års behan dling får en fase hvor de opplever det som "verden går under", eller at de kommer inn i "et sort mørke", som vitner om slike tidlige separasjonstraumer. $\mathrm{N}$ oen analytikere beskriver det som "den psykotiske kjernen" hvor suicidale impulser kan bli uttalt (M cD ougall 1983, 1989). I en slik fase av en terapi er det viktig at timene ikke blir for sjeldne, og at terapeuten er tilgjengelig mellom timene.

U nder en psykoterapeutisk behandling av en periodevis paranoid kvinne i 30 -årsalderen, opplevde jeg at hun etter flere års terapi fikk en tre uker lang psykotisk forvirring med en intens opplevelse av å være forlatt og helt ensom i verden, ingen var der. D en psykotiske episoden ble utløst av et brudd i et forhold til en mann hvor hun hadde engasjert seg sterkere enn i noe tidligere forhold. H un opplevde da at heller ikke jeg som hennes terapeut fantes, selv om hun klarteå komme til timene tre ganger $\mathrm{i}$ uken. $\mathrm{H}$ un røpet etter hvert en skuffelse over at hennes fantasier i overføringen om en helt urealistisk totalomsorg fra min side ikke ble innfridd. M en i ettertid kom det frem ting som tydet på at de faste timene med meg allikevel bidro til at pasienten ikke suiciderte. På ett plan var jeg der likevel. På oppfordring fra pasienten hadde jeg en samtale med faren som fortalte at pasientens mor etter fødselen ikke var i stand til å ta seg av barnet, mye på grunn av konflikter i ekteskapet.

$M$ oren hadde også hatt tvangstanker om å drepe datteren. I tre-fireårsalderen var pasienten i en periode fjern, uten kontakt med omgivelsene. D enne tidlige deprivasjonen var et av flere problemområder som kunne bli løst i terapien som fortsatte i flere år.

En mors depresjon kan oppleves av et lite barn som om mor ikke er der, selv om hun er fysisk til stede. Dette er ofte undervurdert som bakgrunn for depresjoner og selvmord, og blir ofte misoppfattet som en genetisk arv. Den franske psykiater og psykoanalytiker A ndre G reen har i en kjent artikkel: "T he dead mother" beskrevet dette fenomenet ( $G$ reen 1983). $\mathrm{H}$ an sier at det i slike tilfeller ikke blir et effektivt brudd mellom mor og barn, men at barnet i sin fantasi forsøker med hele seg å nære den "døde" mor og å opprettholde en total omslutning av henne. $M$ en resultatet blir "en sort depresjon" og "et sort hull" som blant annet kan resultere i regressive ønsker om inkorporering, dissosiasjon mellom kropp og psyke og et tap av mening. Suicid kan bli en nærliggende konsekvens.

En ung kvinne som var innlagt på en psykiatrisk avdeling for en affektiv lidelse, ble i psykoterapien med en ung mannlig terapeut, sterkt knyttet til ham. Da hun ble bedre, fikk hun permisjon for å dra hjem til foreldrene, men da hun kom dit, oppdaget hun at de var bortreist uten å ha varslet henne. $\mathrm{H}$ un ringte da til sykehuset for å få kontakt med sin terapeut. D a fikk hun beskjed om at han også var bortreist, uten at hun hadde fått vite det. $\mathrm{H}$ un gjorde da selvmord med en stor dose av morens sovetabletter. $\mathrm{N}$ oe av bakgrunnen var at faren som offiser under annen verdenskrig var borte fra hjemmet i hennes første fem år. D ette hadde preget moren med en langvarig depresjon, som hadde gjort det vanskelig for henne å gi tilstrekkelig trygghet og omsorg til sitt første barn. D et var sannsynligvis heller ikke tilfeldig at hun brukte morens sovetabletter, da forholdet til moren var svært konfliktfylt. Pasienten var både intelligent og pen, men svært umoden og sårbar for skuffelser og atskillelser, en sårbarhet som terapeuten og avdelingsmiljøet ikke hadde sett klart nok.

Det er ikke bare tap av mennesker som kan utløse selvmord. Det gjelder også tap av sosial status, "tape ansikt", miste jobben, miste kroppsdeler eller hel sen, og alt som rammer selvbildet og selvfølelsen. Sosial isolasjon gjennom lengre tid vet vi er en årsak til selvmord hos gamle, særlig etter at de har mistet ektefellen eller andre nære pårørende som de har vært knyttet til. Dette er en tragisk situasjon, ikke minst for gamle i storbyer hvor det menneskelige nettverk ofte mangler og aldersomsorgen kan være mangelfull (Jørstad 1988).
H os yngre personer med stadige appellerende selvmordsforsøk og andre former for utagering, kan det oppstå en liknende situasjon. M ennesker rundt dem kan etter hvert bli oppbrukt så de ikke orker lenger, ja de kan gå med halvt bevisste dødsønsker overfor vedkommende. Dette gjelder særlig suicidale personer med ustabile personlighetsforstyrrel ser (borderline), hvor selvfølelsen kan svinge mellom følel sen av grandiositet og verdiløshet, og mellom kjærlighet og hat. Dette vil over tid lett slite ut de som engasjerer seg i vedkommende, enten det er pårørende, venner eller behandlere. $N$ år den suicidale personen oppdager at han/hun egentlig ikke har noen lenger, kan selvmordet bli deres siste handling.

I en sykehusavdeling gjorde en ung kvinne med diagnosen borderline personlighetsforstyrrelse selvmord. Så fort som mulig etter den tragiske hendelsen hadde staben et møte, først sammen med pasientene for at alle kunne komme frem med sine følelser og reaksjoner på det som hadde hendt. Like etter var det et møte med alle som hadde vært engasjert $i$ behandlingen av henne. $H$ ensikten var ikke å finne syndebukker, men forsøke å forstå best mulig hva som hadde ført til dette tragiske forløpet hos en pasient som miljøpersonalet flere måneder hadde engasjert seg sterkt i.

Det kom da frem at mange i miljøet gradvis hadde utviklet fantasier med dødsønsker overfor pasienten, - de ønsket at hun skulle ta livet av seg! D en tankevekkende konklusjonen på møtet var at hvis de hadde klart å snakke åpent med hverandre om disse fantasiene før selvmordet, hadde fantasiene ikke blitt så farlige, og de hadde kanskje unngått at pasienten handlet som hun gjorde?

Dette er et eksempel på hvordan selvmordsprosessen utvikler seg i et samspill med omgivelsene, og hvor det både er et tap av menneskers omsorg og interesse, opplevelsen av ensomhet, og etter hvert en avvisning med dødsønsker, som en suicidal pasient ofte vil føle. U bevisst vil det ofte også være en "smitte" fra pasientens egne følelser (se nedenfor). Det blir en selvforsterkende, vond sirkel som øker for hver dag, hvis ikke noe eller noen klarer å bryte den. 


\section{Å bli krenket}

For at vi skal kunne forstå mer av selvmordprosessen er det avgjørende at vi ser selvfølelsens betydning. Det er når selvfølelsen er svak og synker drastisk som ved tap, eller blir alvorlig krenket, at risikoen for selvmord øker. Vi vet at selvfølelsen grunnlegges i det tidlige mor-barnforholdet, ved at barnet som regel får oppleve at det selv og verden er god, og at det er overvekt av gode opplevelser i forhold til det som er vondt eller mangelfullt. I denne situasjonen blir morens egen selvfølelse som person, kvinne og mor viktig for hennes evne til å formidle dette til sitt barn. Har moren selv en lav selvfølelse, og hvis hun dertil făr liten eller ingen støtte av sin mann eller andre i nærmiljøet, er det en risiko for at barnet også får lav selvfølelse og blir sårbart i senere utviklingsfaser. $M$ en det er også en risiko når en mor føler seg alene og forlatt og ikke har noen støtte i nye og angstvekkende situasjoner.

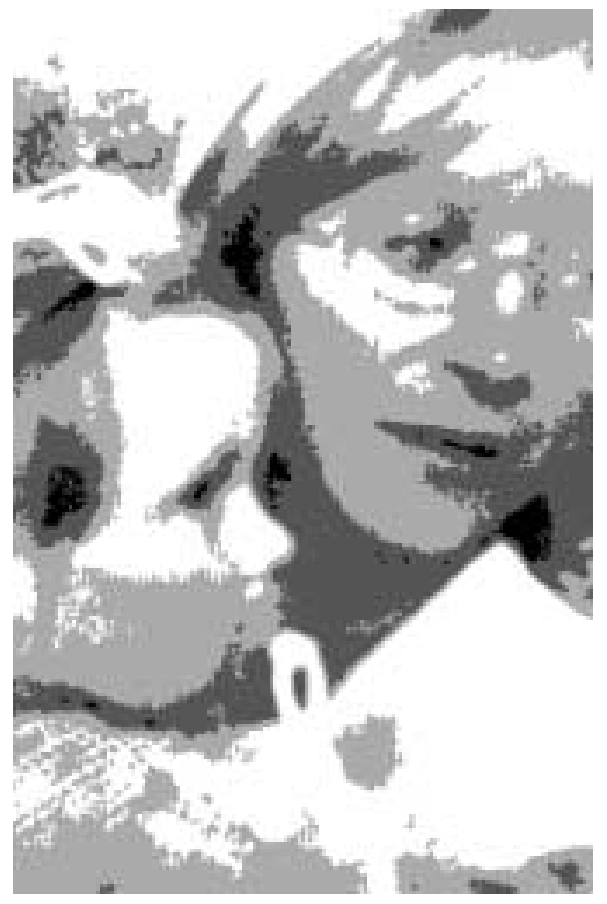

E n 20 år gammel førstegangsfødende kvinne utviklet en fødselsdepresjon på sykehusets fødeavdeling. En psykiater ble tilkalt og vurderte henne som usikker, redd og hjelpeløs overfor sitt nyfødte barn, en bakgrunn for hennes dype depresjon med suicidalfare. $H$ ennes mann virket svært umoden og selvopptatt, og lite forstående og støttende overfor sin kone. To dager etter undersøkelsen hadde hun gått ut av sykehuset, og hengte seg i et uthus i nærheten. $\mathrm{H}$ er var det svikt på flere plan, og mannen som var rasende, anla sak mot sykehuset som han tapte. A t hans egen holdning til sin unge kone også var en viktig faktor i hennes fortvilelse innså han overhodet ikke.

\section{Narsissismens betydning}

Vi må alle ha en viss grad av egenkjærlighet, det vi kan kalle en normal narsissisme, som er grunnlaget for en sunn selvfølelse (Jørstad 1986). Vi er da rimelig glad i oss selv, noe som er en forutsetning for å kunne elske andre. "Elsk din neste som deg selv" er idealet som står i budet. $M$ en en overdreven, patologisk narsissisme er som regel et forsvar mot en utålelig smerte fra barndommen, og ofte er det en følge av foreldres krenkelser av et barns selvfølelse (Jørstad 2001). Personer med et slikt forsvar kan være enormt sårbare for uenighet eller kritikk, og kan da reagere med raseri, da de har liten eller ingen evne til å se sin egen del og sin egen sårbarhet. A It som er galt skyldes andre (projeksjon), og selv har de åpenlyse eller skjulte storhetsforestillinger, en grandiositet som en del av sitt ubevisste forsvar (Jørstad 1995). De har ofte en egen evne til å få makt over andre. Vanligvis er et slikt narsissistisk forsvar sterkt, og fører til at personen kan greie seg mentalt og sosialt, selv om omgivelsene kan bli lidende. $M$ en blir en slik person trengt opp i et hjørne, ved nye krenkelser, eller han mister sitt "selvobjekt" (Kohut 1977, Karterud 1995), eller andre ting gjør at forsvaret ikke holder, kan den skjulte fortvilelsen og hjelpeløsheten bli bevisst, noe som kan gjøre selvmordet til en flukt og en "Iøsning". $\mathrm{N}$ arsissistiske trekk finner vi ofte hos personer som gjennomfører selvmord eller gjør selvmordsforsøk. O fte kan de ha grandiose fantasier om å beherske livet og kontrollere andre ved å ta sitt liv ( $M$ ehlum 1993).

\section{Raseri som vendes innover}

Som nevnt ovenfor kan raseri være en reaksjon på en narsissistisk krenkelse, og blir derved forståelig som et ubevisste forsvar mot en utålelig smerte. $V \mathrm{i}$ vet at det i mange suicidale handlingers psyko- dynamikk er mye aggresjon som blir rettet innover, selv om den er skapt i samspillet med en eller flere andre viktige personer (M enninger 1938). H vordan kan vi forstå at dette raseriet helt eller delvis blir snudd mot personen selv?

En ikke uvanlig erfaring med barn i en viss alder er at de i situasjoner hvor de blir sinte på foreldrene kan si: "Jeg kan dø, jeg, så kan dere ha det så godt!". Som regel blir det med en tanke og en fantasi, men det hender at slike følelser fører til at de forlater hjemmet eller gjemmer seg en stund, for å skremme foreldrene uten at noe drastisk skjer. De har fătt utløp for sitt sinne og hevnbehov, og på en svært effektiv måte skremt de pårørende. $\mathrm{H}$ vis det er store problemer i familien, hender det at også barn gjennomfører et selvmord, noe som heldigvis er sjelden i N orge, men antallet øker i U SA (Retterstøl 1995). $M$ en slike fantasier er ikke sjeldne hos ungdom og voksne personer, særlig ved familiekonflikter og kriser i kjærlighetsforhold. $\mathrm{H}$ atet mellom nære pårørende kan bli morderisk.

I en familie hadde det gjennom lengre tid bygget seg opp en voldsom konflikt mellom en autoritær og konservativ far og en 17 år gammel sønn. Bakgrunnen var blant annet at sønnen hadde latt håret sitt vokse langt, og at han var med i et jazzband hvor det ble brukt litt hasj. D et var i perioden da B eatles var de store forbilder. En morgen på hytta ved frokostbordet var det en intens, taus spenning i hele familien, preget av konflikten mellom far og sønn. Plutselig bryter sønnen tausheten og sier: "J eg går og henger meg, jeg!" "Ja, gjør det du!" sa faren, hvorpå gutten reiste seg og gikk ut. Fem minutter senere fant de ham hengt i skålen.

I "M ourning and melancholia" tar Freud opp likheter og forskjeller mellom normal sorg og melankoli, den alvorligste form for depresjon, hvor risikoen for selvmord er stor (Freud 1917). N oe forenklet sier han at en normal sorg kommer etter et tap av en (hovedsakelig) elsket person, mensen melankoli som regel kommer etter tap av en person (et objekt), hvor forholdet har vært ambivalent, med overvekt av aggressive følelser overfor den tapte person. For å forklare dette beskriver Freud hvordan vi "tar inn" i oss nære personer 
ved hjelp av identifikasjon, i sin mest primitive form ved å "sluke" den andre (introjeksjon). Ved tap av denne person vil den aggressive delen av ambivalensen rettes mot det indre objekt. På grunn av samvittigheten vår, Freuds superego, vil aggresjonen også rettes mot personens eget selv. Jo strengere samvittigheten er, desto mer vil anklager og skyldfølelse ( for de aggressivefølelsene) prege melankolikerenstankeinnhold og eventuelle fordømmende hallusinasjoner, og selvmord kan bli resultatet. Selv om mange i dag mener at alvorlige affektive lidelser er mest arvelig betinget, er det min erfaring at denne dynamikken også kan være virksom ved slike lidelser. Sammen med de narsissistiske elementer i personen vil et tap på et ubevisst plan kunne føles som en krenkelse, og bidra til å utløse et selvmord.

\section{Motoverføringsproblemer}

$M$ otoverføring vil jeg definere som alle de bevisste og ubevisste følelser som en behandler kan få i nærkontakt med en pasient (Kernberg 1965). Vi ser i dag på slike motoverføringer både som uttrykk for en ubevisst kommunikasjon fra pasienten, og et primitivt forsvar, en projektiv identifikasjon som kan påvirke mottakeren meget sterkt. Dette blir særlig uttalt hos personer som har en borderline personlighetsforstyrrelse, noe mange av de som gjør selvmordsforsøk har. Fordi det ofte er både hjelpeløshet og mye raseri og sadistisk aggresjon i den suicidale personen som projiseres på oss behandlere, blir det en årsak til at behandlingen og håndteringen av suicidale pasienter er en av de vanskeligste oppgaver vi har i primærhelsetjenesten og i psykiatrisk arbeid. $V$ årt forsvar mot vårt eget ubevisste motoverføringshat kan bli en hindring for å forstå hva som foregår mellom pasienten og oss. De morderiske fantasiene i et miljøpersonale som er beskrevet foran, er et eksempel på et kollektivt motoverføringshat. Jeg har skrevet om disse problemene utførlig annet sted (Jørstad 1986).

\section{Hva kan vi gjøre for å bryte selvmordsprosessen?}

Det er ikke enkelt å gi et kort svar på dette, både fordi prosessen ofte er skjult eller ubevisst, og fordi den er forskjellig fra person til person. $U$ ansett årsak blir det avgjørende om vi får etablert en tillitsfull kontakt med den suicidale personen, og at denne kontakten kan vare tilstrekkelig lenge til den aktuelle krisen er over. Det motvirker følelsen av å være alene og forlatt. N oen forutsetninger for denne første og ofte avgjørende kontakten er at vi som terapeuter forstår både noe av sårbarheten til personen, og hvordan den aktuelle krisen har rammet denne sårbarheten. Eventuelle tap og krenkelser er viktige temaer som vi må hjel pe pasienten til å snakke om. D et krever mer tid enn et par samtaler. $V$ år holdning må være støtten de så vi kan formidle vår forståelse på en empatisk måte, noe som kan bli grunnlaget for en videre kontakt, eventuelt i en lengre psykoterapi. Terapeutisk erfaring viser at det er viktig å snakke direkte og åpent om de suicidale fantasiene, hvilke metoder de har tenkt å ta livet sitt med, og hvordan de opplever sin situasjon. En forutsetning for dette er at vi som terapeuter har en psykodynamisk trening og erfaring, ikke minst for å kunne forstå og "bære" de projektive overføringer som vi kan bli utsatt for $i$ arbeidet med suicidal pasienter. Etter at vi har lyttet til det pasienten formidler, og når det er etablert en god nok kontakt, er neste skritt å satse på den del av pasienten som vil leve. Vi må peke på de destruktive konsekvensene av et selvmord, både for pasienten og andre, og snakke om muligheter for å forandre forhold til personer som har vært involvert i den aktuelle krisen. $V$ år holdning må være preget av real istisk optimisme, som kan formidle håp og muligheter i fremtiden. Er det personlighetsproblemer, bør pasienten henvises til mer intensiv psykoterapi etter at den akutte suicidale krisen er over. A ntidepressiva vil også være nødvendig hos mange pasienter med alvorlige, affektive lidel ser.

Enten det gjelder ambulant behandling hos psykiatere og psykologer, eller i psykiatriske avdelinger, forutsetter en god behandling og håndtering av suicidale pasienter at terapeutene og miljøpersonalet i en avdeling har en psykodynamisk forståelse og erfaring. M angler dette, mener jeg at behandlingen i beste fall blir mangelfull, i verste fall risikabel.

\section{Referanser}

Bowl by J. D eprivation of maternal care. N ew York: Schocken Press, 1966.

Freud S. M ourning and melancholia. London: Hogarth Press, 1917.

Green $A$. T he dead mother. In $G$ reen $A$.: On private madness. $M$ adison, $C$ onnecticutt: Int. U niversity Press, 1983.

HolmesTH.\& Rahe RH.T he social readjustment rating scale. J Psychosomat Res 1967; 11: 213-218.

Jørstad J. N oen erfaringer med suicidale pasienter. O slo: O rganon, 1986:43-50.

Jørstad J. Sånn er livet, sånn er du og jeg. O slo: A schehoug, 1986, Stockholm 1988, København 1988, G dansk 1998.

Jørstad J. Psykodynamiske synspunkter på depresjoner. O slo: O rganon, 1988: 39-49.

Jørstad J. B alanseganger. 0 slo: A schehoug 1995, Stockholm 1997, København 1998, London 2001.

Jørstad J. Avoiding unbearable pain. R esistance and defence in the psychoanalysis of a man with a narcissistic personality disorder. Scand Psychoanal Rev 2001; 24: 34-45.

Karterud S. Fra narsissisme til selvpsykologi.

O slo: A d N otam, 1995.

Kernberg $O$. N otes on countertransference. J A meric Psychoanal A ss 1965, 13: 38-56.

Kohut $H$. T he restoration of the self. $N$ ew York: Int U niv Press, 1977.

M ahler M S., Pine F. \& Bergman A. T he psychological birth of the human infant. London: H utchinson, 1975.

M cD ougall J. A lexithymia, psychosomatosis and psychosis. Int J Psychoanal Psychther. 1982-83; 9: 379-88.

M CD ougall J. T heaters of the body. N ew York: N orthon: 1989.

M ehlum L. Såret som ikke ville gro. $0 \mathrm{~m}$ selvmord i traumeperspektiv. I: M ennesker, traumer og kriser. O sl o: U niversitetsforlaget, 1993: 178-89.

M enninger $\mathrm{K}$. M an against himself. $\mathrm{N}$ ew York: $\mathrm{H}$ arcourt, Brace W orld Inc., 1938.

Retterstøl N. Selvmord. O slo: U niversitetsforlaget, 1995.

Spitz RA. The first year of life. N ew York: Int Univ Press, 1965.

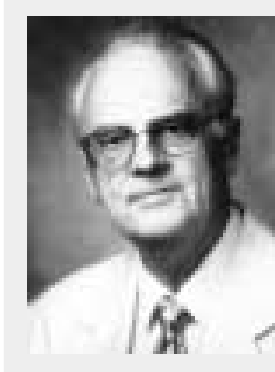
Jarl Jørstad er psykiater og psykoanalytiker. $\mathrm{H}$ an var overlege i 12 år på Dikemark sykehus, avdeling Lien, og avdelingsoverlege i 14 1/2 år på U Ilevål sykehus, Psykiatrisk avdeling. Fra $1990 \mathrm{i}$ privat psykoterapeutisk og psykoanalytisk praksis, og med mange veilednings- og undervisningsoppdrag. $\mathrm{H}$ an har publisert mange vitenskapelige artikler og to populærvitenskapelige bøker. 